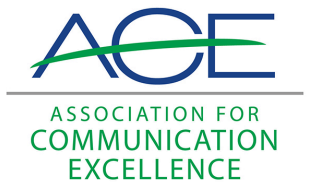

Journal of Applied Communications

\title{
Publish: The How-to Magazine of Desktop Publishing; Personal Publishing: The Magazine for Desktop Publishers; PC Publishing:The Desktop Publishing Magazine for IBM \& Compatible PC Users
}

Jim Shaner

Jim King

Darcy Meeker

Follow this and additional works at: https://newprairiepress.org/jac (c) (i)(2)

This work is licensed under a Creative Commons Attribution-Noncommercial-Share Alike 4.0 License.

\section{Recommended Citation}

Shaner, Jim; King, Jim; and Meeker, Darcy (1987) "Publish: The How-to Magazine of Desktop Publishing; Personal Publishing: The Magazine for Desktop Publishers; PC Publishing:The Desktop Publishing Magazine for IBM \& Compatible PC Users," Journal of Applied Communications: Vol. 70: Iss. 4. https://doi.org/10.4148/1051-0834.1596

This Review is brought to you for free and open access by New Prairie Press. It has been accepted for inclusion in Journal of Applied Communications by an authorized administrator of New Prairie Press. For more information, please contact cads@k-state.edu. 
Publish: The How-to Magazine of Desktop Publishing; Personal Publishing: The Magazine for Desktop Publishers; PC Publishing:The Desktop Publishing Magazine for IBM \& Compatible PC Users

\author{
Abstract \\ Reviews of Publish: The How-to Magazine of Desktop Publishing; Personal Publishing: The Magazine for \\ Desktop Publishers; PC Publishing: The Destop Publishing Magazine for IBM \& Compatible PC Users; \\ People's Workbook: Environmental and Development Agency (EDA) ; "Technology and Learning," from \\ Lawrence Erlbaum Associates ; Instructional Technology: Foundations, edited by Robert M. Gagne; "Art \\ for Art's Sake," by Alfie Kahn.
}


Desktop and computer-aided publishing changes so quickly-and effectively-l think there's no overstatement in likening these changes to a printing revolution. The three magazines noted in the following review are published to guide journalists and designers through the software and hardware decisions they have to make-or to guide computer specialists through the unfamiliar territory of offset production and publications design. Advertising support is strong; each magazine serves readers and advertisers with convenient product information cards. At different levels, all three strive to be desktop laboratories that test hardware and software in their own publication process.

\section{Publish: The How-to Magazine of Desktop Publishing; PCW Communications, Inc., 501 Second St., San Francisco, CA 94107; subscriptions, $\$ 39.90$ annually; roughly 110 pages.}

The maiden issue of Publish was itself published within another magazine-the July, 1986, issue of PC World. I recommend that issue of World as the best summary of desktop publishing and the best statement of the differences between it and full offset production that I have read.

With that birth, you might expect Publish to emphasize the desktop publishing contributions of IBM and its clones. Not so, if anything, Apple Macintosh news and reviews seem to dominate. Besides the personal computer approach to publishing, Publish examines such microcomputer systems and workstations as Sun and Apollo. So computer-assisted, as well as desktop, publishing is included in its scope.

Cover stories tend to be substantive and timely, with the August issue stressing copyright considerations. Regular features include redesigns of publications at the economical end of the offset scale-newsletters and technical data sheets. Besides the redesign, authors provide comments on both the original design and their improvement. They even provide brief software data on the word processing and graphics software they used in the redesign, together with the hardware involved and any special configuration it might have.

Boxed tips, published each issue, provide help from routine maintenance to fixes or tricks to get programs or hardware to do the things they were designed to do, and some they "can't."

Finally, and most importantly, the staff of Publish do the design of this national magazine on microcomputers using stan- 
dard software programs. Most line art is produced on microcomputers by using draw and paint programs. But they produce Publish through a modified offset process. A Macintosh system drives full offset typesetters. The Apple LaserWriter printer is only used as a low resolution proofing machine. Photographs are reproduced the traditional way, with standard screens and film.

\section{Personal Publishing: The Magazine for Desktop Publishers; The Renegade Company, P.O. Box 390, Itasca, Illinois 60143; subscriptions, $\$ 30$ annually, roughly $100 \mathrm{pp}$.}

Like Publish, Personal Publishing provides a testing laboratory for desktop products with the publication of every issue. But they take their desktop laboratory one step further. Unlike Publish, Personal Publishing does not switch to a full offset system for their final product. The entire magazine is produced at standard desktop resolution-300 dots per inch for a single line-unless otherwise specified-rather than the higher resolution of 1,200 to $2,400 \mathrm{dpi}$ of full offset production.

Personal Publishing takes the training role, implied in their laboratory approach, more seriously than Publish. Their writing is more didactic. Like Publish, screens from software programs are reproduced with steps showing how to use the program. But Personal Publishing includes screens and steps more as examples of how to work through the software than as basis for software comparisons.

Typically, the staff works through a software review in detail, step-by-step, providing examples of the program's output in the review itself-including samples of what can be done with some of a programs's special effects. In their September issue, Personal Publishing showed how to use special capabilities of a software program to place and screen a dot pattern so it becomes a car's exhaust. Then the writer reports the changes in the setting of the laser printer that preserved the exhaust effect for publication.

The writing and design in Personal Publishing are not as smooth as that of Publish. Their issues do not celebrate the revolution and inform us about it, as Publish does. Instead, they provide more how-tos and examples for doing it. But sometimes their design and examples get in the way of the message. Overall, their teaching approach is clear, rich in examples, but presented with the style and grace of a manual. Personal Publishing is more likely to present the nitty gritty aspects in its comparisons, for those of us who might need them.

Advertisers are well represented. A convenient mail ordering card provides easy access to additional information for both advertising and reviews-which are coded as well. Personal Publishing is not as much fun to read-but it is fun, and it's good for you! 


\section{PC Publishing:The Desktop Publishing Magazine for IBM \& Compatible PC Users; Hunter Publishing Company, Inc., 950 Lee Street, Des Plaines, IL 60016; subscriptions, \$36 annually, roughly $70 \mathrm{pp}$.}

PC Publishing, as the name implies, limits its hardware and software coverage to IBM and its clones. The staff takes the desktop laboratory another step by testing microcomputers in Publishing's desktop production process. The September 1987 issue was produced with Hewlett Packard's Vectra PC, and the editors complete the test by briefly reporting the Vectra's strengths.

The magazine features a series of "Hands-on" sectionsHands-on Fonts provides an overview of fonts and typefaces, generally, together with a brief overview of several PC font packages. Hands-on PageMaker and Hands-on Ventura Publisher present nuances and fixes, often user-discovered, for these products.

PC Publishing's references to advertisers is more basic than the others, although it offers reader service cards. Briefs in the fonts article, for example, began with the name, address, zip code, and telephone number of the company that produced each font.

The magazine's writing and design are personal, but stodgy. Typos, and such typical word processing mistakes as omissions, are legion. PC Publishing reads like a newsletter produced by a local computer user group, rather than by journalists. Its authors approach publishing more as a test of equipment and software than as a product in itself. Reviews tend to emphasize printer ports and computer workings rather than design effects.

I'd recommend it for technicains and programmers that keep desktop systems going, rather than for the journalists and designers who use them.

Jim Shaner

University of Missouri-Columbia

\section{People's Workbook: Environmental and Development Agency (EDA), Box 62054, Marshalltown, 2107 Johannesburg, South Africa. (ISBN 062005355 0) \$10.00. 560 pp.}

Tinkabi tractors, making a mud stove, having a baby at home, making sandals - these are but a few of the many techniques and technologies this tremendous volume covers. It also gives the Westerner an interesting view of the South African rural sector.

The major topics are homestead farming, crops, trees, animals, water, pregnancy, and child care, legal rights, working in groups, 
Journal of Applied Communications, Vol. 70, Iss. 4 [1987], Art. 5

and buildings. An excellent section covers resources-suppliers, the organizing of seed and food buying groups, advice organizations, and books, together with suggestions on how to start a library.

You know you have something special in your hands from the front and back covers-black and white linocut prints of rural African scenes. And when you read the 20-page comic, "Vusi Goes Back," the visual story of a man visiting his family in the Transkei and learning the history of his people from his grandfather, you'll be glad you got the book-you'll be depressed, yet you'll want more.

The People's Workbook stresses self-sufficiency and offers practical advice on using local resources and knowledge to better life. It is really too big and too diverse to properly review here. Extension workers and ACE members working with the developing world will find much practical advice which is not cultural specific.

I'm sure there are gaps in People's Workbook and that some technical information may be missing. But I am taken by the mass amount of information that is geared to rural audiences and the over 600 drawings and photographs that add to its populist impact. This book is an excellent model, stressing community participation, that could be used for the rural sector in many countries. Only $\$ 10$, People's Workbook is a "must" for anyone working in rural development in Africa.

Jim King

University of Nebraska-Lincoln

\begin{abstract}
"Technology and Learning," from Lawrence. Erlbaum Associates, Inc. 365 Broadway, Hillsdale, NJ 07642. (Six issues per volume, per year-\$14.00, individual; $\$ \mathbf{2 4 . 0 0}$ institutional; Subscriptions only on a volume basis).
\end{abstract}

This is a new newsletter. Its purpose is to enhance open communication by "providing an informal, comprehensive, and immediate communications network" for those "involved in changing education through new technology."

To do this the editors have assembled a distinguished advisory board. This highly productive board includes individuals from university, business, military, and private settings, spanning worldwide interests. IBM, Harvard, AT\&T, Carnegie-Melon, Educational Testing Service, and Xerox are but a few of the groups represented.

I was surprised to find that the main thrust of "Technology and Learning" really focuses on computer applications to learning. 
Yet there is enough crossover information on learning and message design that educational developers who are not computer oriented will find solid and very up-to-date material for their own uses.

One innovative column, "preprint market," presents papers or abstracts that have not yet been published. This is an excellent method to get new information to users quickly, while retaining the "right" journals for expanded and referred articles. The "publications" section contains titles, addresses and very brief descriptions of current, (this year, last month) books and journals.

Articles in the first three issues have dealt with computer aids in Swedish classrooms, tools for intelligent CAE systems, the Systems Thinking and Curriculum Innovation Project, and intelligent tutoring systems. "Everyone Will be a Programmer" is a first-hand report from an award winning middle school teacher on his experience with technology in education. Those issues also include the BESTNET project about interactive Spanish/English transition telecourses and some papers on the philosophy of technology, education, and learning.

This 12-page newsletter has me feeling that I am keeping up with the "latest" developments. I may not understand them all, but I know they are there, I know who is doing them, and I know where I can go for further information.

Technology and Learning is a good newsletter; the information is timely and credible; the cost is right; it is quick to read; and you can circulate it rapidly within your department.

Jim King

University of Nebraska-Lincoln

\begin{abstract}
Instructional Technology: Foundations. Edited by Robert M. Gagne. 1987. Lawrence Erlbaum Associates, Inc. 365 Broadway, Hillsdale, NJ 07642. 480 pp. (\$59.95, cloth; \$24.95, paper).
\end{abstract}

Don't be intimidated by this big book geared for a graduate level class. It contains insider descriptions of both the theoretical and practical implications of high-tech development for instruction. These include audio-visual systems, telecommunications, computer aided instruction (CAl), and intelligent CAI.

For ACE communicators who do not have a background in instructional technology and learning theory, chapters on learning research, systems design, task analysis, and instructional models will prove valuable. Other chapters will update educators in the newest research on learner characteristics and message design. 
Also discussed are innovations in telecommunications (satellites, teleconferencing, fiberoptics, videodisc, videotext, and others), computer-aided systems, artificial intelligence, and computerbased learning. Other sections on evaluation, planning and systems development convey the full "systems approach."

Two chapters make this book special. One gives an account of the factors affecting the use of the results and products of instructional development. That chapter reviews and updates diffusion and adoption literature. A second brings together the several trends in thought and effort that contribute to instructional technology. It's hard to find a better historical summary.

Authors in this collection read like a who's who of very senior researchers and practitioners in the field of instructional technology-Gagne, Reiser, Banathy, Kaufman, Thiagarajan, Merrill, Reigeluth, Tobias, Fleming, Nugent, Tennyson, Baker, Morgan. The general approach of the writing throughout the book follows Gagne's "conditions of learning." This proven educational psychology approach to learning specifies the conditions to meet for learning to occur.

However, if Gagne's book were your only source on instructional technology, you might have an exaggerated idea of the significance of the ideas and processes. But you would know more about theories and approaches than most instructional developers. Nervertheless, the 16 chapters effectively describe the state of the art in the field of instructional technology. Current, effective techniques, problems yet to be solved, and potentialities for the imporvement of instruction are well presented.

Instructional Technology is a large and expensive book, full of practical information for those of us in the field of agricultural communication. If your business is designing and developing learning materials for adults and children, and you employ educational "media" hardware to deliver educational messages, you will find new ideas and approaches in this volume.

Jim King

University of Nebraska-Lincoln

\section{"Art for Art's Sake," by Alfie Kohn in Psychology Today, (September, 1987), Ziff-Davis Publishing Co., New York, New York), pp. 52-57.}

How do you best stimulate creativity in your staff? Praise? Competition? Pay raise?

None of the above. 
In "Art for Art's Sake," Psychology Today (September, 1987) reports on 10 years of creativity research by Teresa Amabile at Brandeis University in Waltham, Mass.

Among her findings:

- Children who were told they would receive an award for drawing with magic markers spent less time playing with the markers than did those who got no award.

- Competition also seems to inhibit creativity.

- Concentrating on impressing teachers, making money and getting into graduate school led one group of students to write more poorly.

Amabile calls her conclusions The Intrinsic Motivation Principle of Ceativity: "People will be most creative when they feel motivated primarily by the interest, enjoyment, satisfaction and challenge of the work itself-and not by external presures."

Psychology Today cites other research that corroborates her findings that surveillance, deadlines and evaluation all undermine intrinsic interest in an activity, and, therefore, can undermine creativity.

Conventional motivators can be useful in the creative process, in stage one, the information/fact gathering stage; and in stage three, validating and communicationg the idea.

Stage two, however-"dreaming up a new idea-is more apt to happen when the motivation is love rather than money."

Amabile's findings challenge the behaviorists' assumption that creatures act the way they do to gain rewards.

A questionnaire completed by 1,200 people indicates that task satisfaction (intrinsic motivation) correlates with creativity, and a strong need for others' approval correlates with lack of creativity. A person's interest in money does not predict anything about his or her creativity.

Support from managers and time enough to do a job well are part of managing for creativity; you cannot manage creativity directly, Amabile reports.

Reprints of "Art for Art's Sake," from the September, 1987, Psychology Today can be ordered from Psychology Today Reprints (619-755-1199) at P.O. Box 400, Del Mar CA 92014. They take telephone orders with credit cards. Costs run 64 cents each for 20 copies, 58 cents for 100 . There's a minimum order and a $\$ 2$ charge for processing and shipping. 


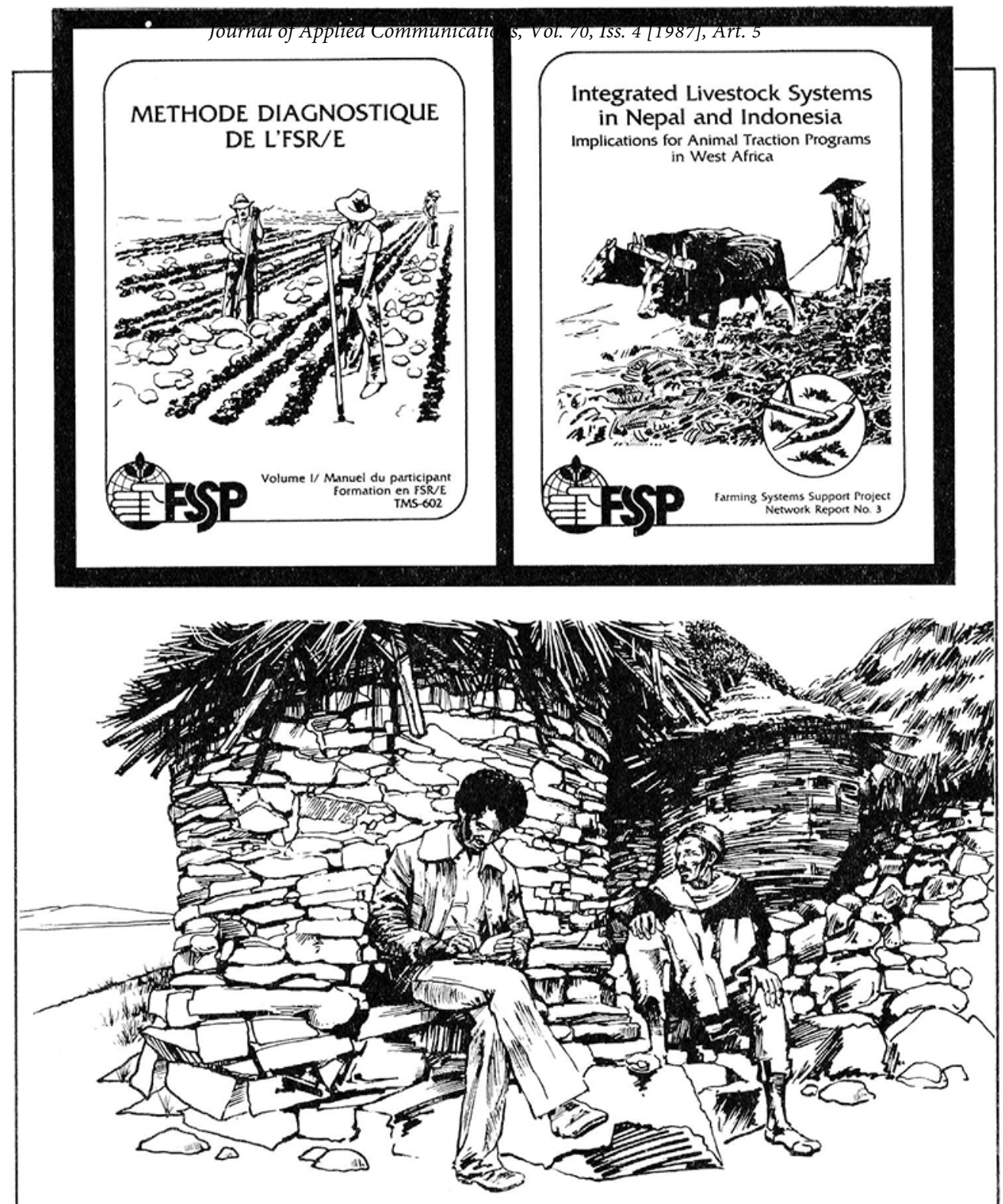

The research/extension interface has become an important focus for agricultural technical assistance in developing countries. Farmer participation in on-farm trials used to test various technologies provides necessary feedback into the technology generation process. Training materials and network reports provide guidelines for and documentation of field activities. These design marker illustrations have provided a thematic cover scheme, silkscreened in two-colors on polyvinyl for durability in the tropics and in the field. Reed Pedlow designer/illustrator, former member of $A C E$ works for IFAS, Editorial Department, University of Florida. 